\title{
ANTIOXIDANT AND ANTIDIABETIC POTENTIALS OF Cucurbita pepo LEAVES EXTRACT FROM THE GULF REGION
}

\author{
S. Chigurupati ${ }^{1, \bowtie}$, Y.K. AlGobaisy ${ }^{1}$, B. Alkhalifah ${ }^{2}$, A. Alhowail ${ }^{3}$, \\ S. Bhatia ${ }^{4,5}$, S. Das ${ }^{6}$ and S. Vijayabalan ${ }^{7}$ \\ ${ }^{1}$ Department of Medicinal Chemistry and Pharmacognosy, College of Pharmacy, Qassim \\ University, Buraydah 52571, Kingdom of Saudi Arabia. \\ ${ }^{2}$ Department of Radiology, College of Medicine and Medical Sciences, Qassim University, Al \\ Qassim Region, Unaizah 56219, Kingdom of Saudi Arabia. \\ ${ }^{3}$ Department of Pharmacology and Toxicology, College of Pharmacy, Qassim University, \\ Buraydah 51452, Kingdom of Saudi Arabia. \\ ${ }^{4}$ Natural \& Medical Sciences Research Center, University of Nizwa, P.O. Box 33, 616 Birkat Al \\ Mauz, Nizwa, Oman. \\ ${ }^{5}$ School of Health Science, University of Petroleum and Energy Studies, Dehradun, Uttarakhand \\ 248007, India. \\ ${ }^{6}$ Department of Pharmacology, AIMST University, Semeling,08100 Bedong, Kedah, Malaysia. \\ ${ }^{7}$ School of Pharmacy, Faculty of Health and Medical Sciences, Taylor's University, Subang \\ Jaya, Kuala Lumpur, 47500, Malaysia. \\ ${ }^{\otimes}$ Corresponding Author: sridevi.phd@gmail.com
}

\begin{abstract}
Cucurbita pepo has been known to be used as a folk medicine for treating many disorders such as ulcers, intestinal parasites, urinary tract disorders, and as an anti-diabetic agent in the gulf region. Quantitative analyses of ethyl acetate solvent of $C$. pepo leaves were performed, and the total phenol and flavonoid contents were quantified as $32.6 \pm 0.17$ $\mathrm{mg} \mathrm{GAE} / \mathrm{g}$ and $80.5 \pm 0.02 \mathrm{mg}$ RUE/g, respectively. The results of antioxidant studies by DPPH method had shown that CPLE has an $\mathrm{IC}_{50}: 49.31 \pm 0.21 \mu \mathrm{g} / \mathrm{mL}$ and in ABTS assay CPLE showed an $\mathrm{IC}_{50}: 48.67 \pm 0.27 \mu \mathrm{g} / \mathrm{mL}$. In antidiabetic analysis studies using $\alpha$-amylase enzyme inhibitory assay, it was found that CPLE exhibited an IC $50: 24.99$ $\pm 0.07 \mu \mathrm{g} / \mathrm{mL}$ contrasted to Acarbose (standard drug) with an $\mathrm{IC}_{50}: 19.45 \pm 0.19 \mu \mathrm{g} / \mathrm{mL}$. Also, in $\alpha$-glucosidase enzyme inhibitory assay, CPLE exhibited $\mathrm{IC}_{50}: 22.29 \pm 0.27 \mu \mathrm{g} / \mathrm{mL}$, whereas acarbose exhibited $\mathrm{IC}_{50}: 16.70 \pm 0.99 \mu \mathrm{g} / \mathrm{mL}$. CPLE can be used and suggested as a remedy for radical scavenging and diabetes therapy after further clinical investigations.
\end{abstract}

Keywords: Cucurbita pepo, Antioxidant, Anti-diabetic, $\alpha$-amylase, $\alpha$-glucosidase.

RASĀYAN J. Chem., Vol. 14, No.4, 2021

\section{INTRODUCTION}

Plants throughout history were considered a thorough part of pharmacotherapy; hence the development of natural medicine is focussed. ${ }^{1}$ Many medicinal or ancient-used plants have been used as complementary medicine and pharmaceutical manufacturers are still working on plant research to expand information and to conduct novel discoveries. Cucurbita pepo is an annual plant that was domesticated throughout the Americas; it belongs to the family Cucurbitaceae. C. pepo could also be referred to as squash, pumpkin, zucchini, courgette, and gourd has a total of eight divisions according to their shapes and varies slightly in their compositions, the squash leaves were used in the present study. C. pepo leaves are considered edible, especially in Korea, India and in many places of Africa and it has been used as an anti-diabetic agent and also for parasite or worm management in many countries as a folk medicine ${ }^{2}$ and it also proved to show significant improvement in benign prostatic hyperplasia related urinary symptoms. ${ }^{3}$ The Kingdom of Saudi Arabia globally is considered among the top 10 highest countries according to diabetes mellitus prevalence. ${ }^{4}$

Rasayan J. Chem., 14(4), 2357-2362(2021)

http://doi.org/10.31788/RJC.2021.1446455

This work is licensed under a CC BY 4.0 license. 
Recently, research is focused on C. pepo, which proved to possess antibacterial ${ }^{5}$, antioxidative ${ }^{6}$, analgesic, and anti-inflammatory activities. ${ }^{7}$ Pumpkin seeds are known to possess active ingredients, magnesium salts, zinc, linoleic acid, stearic acid, oleic acid and stearic acid. Pumpkins also comprise biologically active elements like peptides, proteins and polysaccharides. ${ }^{8}$

Antioxidants, both natural and synthetic play an important role in preventing or delaying cellular damage caused by oxidative stress or free radicals. Most of the biological studies on C. pepo were focused on its fruit hull or pulp and there are only limited studies reported on leaves. ${ }^{9,10}$ To our comprehension, this is the preliminary scientific finding incorporating the potential use of $C$. pepo leaves as an antioxidant and an anti-diabetic agent from a Saudi Arabian geographical zone (gulf region). Based on the literature, we planned to investigate the phytochemical contents, antioxidant, alpha $(\alpha)$-amylase, and alpha $(\alpha)$ glucosidase inhibitory potentiality of C. pepo leaf ethyl acetate extract.

\section{Material and Methods}

\section{EXPERIMENTAL}

Gallic acid (GA), 2, 2'-Azino-bis (3-Ethylbenzothiazoline-6-sulphonic acid (ABTS), Rutin, intestinal $\alpha$ glucosidase, and pancreatic $\alpha$ - amylase procured from Sigma-Aldrich Corporation (USA). 2, 2-Diphenyl1-picrylhydrazyl (DPPH) procured from Cayman Chemical Company (USA). Reagents and chemicals used in the analysis were obtained from Fouz Chemical Company (Saudi Arabia).

\section{Plant Material}

C. pepo leaves were obtained from Rama farms, Al-Muthnab, Al-Qassim, Kingdom of Saudi Arabia. C.pepo leaves cultivated collected in a clean bag, washed thoroughly with tap water to remove soil and dirt from their surface. The leaves were distributed and kept to dry in a hot area avoided direct sunlight. After drying, the leaves were grounded and used for extraction through the maceration technique. The C. pepo leaves (plant material) were authenticated by Qassim University, Saudi Arabia (Reference No: $\mathrm{QA} / \mathrm{FOP} / 02)$.

\section{Extract Preparation}

The maceration method was used for the preparation of $C$. pepo leaves extract (CPLE). Powdered $150 \mathrm{~g}$ of leaves were added to $500 \mathrm{~mL}$ of ethyl acetate and the mixture was incubated on a rotatory shaker at 100 rpm continually for 5 days under room temperature and a stepwise extraction from the remaining plant material was performed. The procedure was performed in cycles until a colourless supernatant was observed then filtered the extract through a muslin cloth. ${ }^{11}$ The filtrate obtained was evaporated using a rotary flash evaporator. ${ }^{12}$ The resulting extract was freeze-dried and transferred to an airtight container and stored in a desiccator. The percentage yield was calculated, and the extract was used for further studies.

\section{Qualitative Phytochemical Analysis}

Preliminary screening of phytochemicals including protein, alkaloids, carbohydrate, steroids, glycosides, non-reducing polysaccharides (starch), flavonoids, phenol, gums, saponin and tannins of C. pepo leaves extract using standard biochemical testing methods was performed as described. ${ }^{13}$

\section{Quantitative estimation of Total Phenolic Content (TPC)}

The mixture was made by combining each of $0.1 \mathrm{mg} / \mathrm{mL}$ ethanolic solution $(0.5 \mathrm{~mL})$ of extract, $1 \%$ FolinCiocalteu's reagent $(2.5 \mathrm{~mL})$, along with $0.75 \%$ sodium bicarbonate solution $(2.5 \mathrm{~mL})$. The standard drug, Gallic acid concentrations, are prepared in concentrations of $0.1-1.0 \mathrm{mg} / \mathrm{mL}$ in ethanol. The samples and the standard were incubated at $37^{\circ} \mathrm{C}(30 \mathrm{~min})$. The absorbance reading was taken at $765 \mathrm{~nm}$ from a UV/Vis spectrophotometer. The samples were done in triplicates and the absorbance means were acquired. The absorbance values were represented as mean \pm standard deviation (SD). The blank solution was prepared concomitantly with ethanol rather than extract solution. The calibration line was plotted using Gallic acid values. The TPC of CPLE was calculated and expressed as Gallic acid equivalent in GAE mg/g. ${ }^{12,14}$ The total phenol content (TPC) can be calculated using eqn.-1:

$\mathrm{TPC}=(\mathrm{C} \times \mathrm{V}) / \mathrm{m}$

$\mathrm{C}=$ Concentration of GA from the graph calibration curve in $(\mu \mathrm{g} / \mathrm{mL}), \mathrm{V}=$ Sample volume solution $(\mathrm{mL})$, $\mathrm{m}=$ extract weight $(\mathrm{g})$. 


\section{Quantitative Estimation of Total Flavonoid Content (TFC)}

To estimate TFC of CPLE, a modified spectrophotometric method was used. $0.2 \mathrm{mg} / \mathrm{mL}$ CPLE prepared using methanol as solvent. Rutin was used as a standard drug and prepared in concentrations ranging from $10-1000 \mu \mathrm{g} / \mathrm{mL}$ in methanol solvent. The reaction mixture is prepared by combining $3 \mathrm{~mL}$ of CPLE and $3 \mathrm{ml}$ of $2 \%$ aluminum chloride solution which was dissolved in methanol. Then it was kept at $37^{\circ} \mathrm{C}$ for an hour. The absorbance reading was noted at $415 \mathrm{~nm}$ from UV/Vis spectrophotometer. The samples were done in triplicate and the absorbance mean was acquired and the data were represented as mean \pm Standard Error Mean (SEM). The same process was repeated for the Rutin and the calibration line was plotted. The TFC was calculated and termed as mg Rutin equivalents per gram of dry weight (RUE mg/g) ${ }^{12,15}$. The TFC can be calculated using eqn.-2:

$\mathrm{TFC}=(\mathrm{C} \times \mathrm{V}) / \mathrm{m}$

$\mathrm{C}=$ Concentration of Rutin from the graph calibration curve in $(\mu \mathrm{g} / \mathrm{mL}), \mathrm{V}=$ Sample volume solution $(\mathrm{mL})$, $\mathrm{m}=$ extract weight $(\mathrm{g})$.

\section{In-Vitro Antioxidant Studies \\ DPPH Free Radical Scavenging Method}

Antioxidant activities of CPLE were determined using DPPH reagent ( $2 \mathrm{mM}$ in $95 \%$ ethanol) and were kept in the dark for at least 30 min before adding to extract. DPPH was chosen due it is stability as a free radical. Both the extract (sample) and ascorbic acid (standard) were prepared in a concentration range of $10-1000 \mu \mathrm{g} / \mathrm{mL}$, respectively, with ethanol. Sample stock was prepared by adding $500 \mu \mathrm{L}$ of the extract with $500 \mu \mathrm{L}$ of the DPPH solution. From the stock solution, variant concentration of sample and standard were prepared using the dilution method. Standard concentrations are also prepared in the same method. Control was prepared using $500 \mu \mathrm{L}$ of $95 \%$ ethanol and $500 \mu \mathrm{L}$ DPPH solution. All the solutions were kept at $45^{\circ} \mathrm{C}(20 \mathrm{~min})$ and the absorbance reading was taken at $517 \mathrm{~nm}$ from UV/Vis spectrophotometer. All assays were carried out in triplicates and the mean of each absorbance was recorded. The values are termed as mean \pm SEM (Standard Error Mean) ${ }^{16}$. Inhibition \% of test compounds were calculated using the eqn.3:

$\%$ Inhibition $=[($ Control Absorbance - Sample Absorbance $) /$ Control Absorbance $]$ x 100

\section{ABTS Free Radical Scavenging Method}

The antioxidant ability of CPLE was further estimated using ABTS scavenging method using the procedure described earlier. ${ }^{11,17}$ The absorbance reading was taken at $734 \mathrm{~nm}$ using a UV/Vis spectrophotometer. Accordingly, the procedure was carried out for ascorbic acid (standard) and the $\%$ scavenging (free radicals) was quantified from eq.-3.

\section{Antidiabetic Studies}

\section{Alpha-Amylase Inhibition Method}

Mixture $500 \mu \mathrm{L}$ of CPLE and acarbose at different concentrations $(100-1000 \mu \mathrm{g} / \mathrm{mL})$ were treated each with $500 \mu \mathrm{L} \alpha$-amylase solution $(0.5 \mathrm{mg} / \mathrm{mL})$ in phosphate buffer $(0.2 \mathrm{mM} ; \mathrm{pH} 6.9)$ respectively. Both standard and samples were subjected to incubation for $10 \mathrm{~min}$ at $25^{\circ} \mathrm{C}$. Then, $1 \%$ starch solution was added into the solutions continued with incubation for another $10 \mathrm{~min}$ at $25^{\circ} \mathrm{C}$. Then, dinitro salicylic acid color reagent $(1 \mathrm{~mL})$ was added and incubated in water to boil for $5 \mathrm{~min}$. After incubation, they were left for cooling to room temperature. The reaction mixture was further diluted with distilled water $(10 \mathrm{~mL})$. The absorbance reading was taken at $540 \mathrm{~nm}$ using UV/Vis spectrophotometer. The procedure was done for the control using the solvent without the extract. All assays were carried out in triplicates, and the mean of each absorbance was recorded. The values are expressed as mean $\pm \mathrm{SEM}^{18}$. The $\%$ inhibition of $\alpha$-amylase was quantified from eqn.-3.

\section{Alpha Glucosidase Inhibition Method}

A mixture of $1 \mathrm{~mL}$ of acarbose and CPLE (100-1000 $\mu \mathrm{g} / \mathrm{mL})$ was mixed with $1 \mathrm{~mL}$ of $\alpha$-glucosidase (1 $\mathrm{U} / \mathrm{mL}$ ) at $37^{\circ} \mathrm{C}$ for $5 \mathrm{~min}$. Accordingly, $2 \%$ sucrose $(1 \mathrm{~mL})$ in Tris buffer $(\mathrm{pH} 8)$ was added and kept for 20 min. The mixture was withheld by water to boil for approximately $2 \mathrm{~min}$. Then, the glucose release was 
RASĀYAN J. Chem.

Vol. 14 | No. 4 |2357-2362| October- December | 2021

quantified (glucose peroxidase method) using a standard drug (Acarbose). ${ }^{11}$ The $\%$ inhibition was obtained from eqn.-3.

\section{Statistical Analyses}

All in-vitro quantitative analysis was done in triplicates and the values were stated as mean $\pm \mathrm{SD}$, while antioxidant and antidiabetic study results were expressed as mean \pm SEM. The inhibition concentration acquired for $50 \%\left(\mathrm{IC}_{50}\right)$ inhibition of enzymes along with free radicals was obtained by a non-linear regression graph plotted between the inhibition percentage versus $\log$ concentrations on $\mathrm{x}$ and $\mathrm{y}$ axis respectively, using a Graph Pad Prism Software (Version 5.03).

\section{RESULTS AND DISCUSSION}

Numerous biological studies on C. pepo were centered on its fruit hull, seeds, pulp ${ }^{19}$ and there are only partial studies reported on leaves in south. ${ }^{20}$ This is the first report incorporating the potential use of $C$. pepo leaves from a Saudi Arabian geographical zone. C. pepo leaves extract was prepared from three macerations in a step-wise manner using ethyl acetate as a solvent, the percentage extraction yield of CPLE in our study was found to be $30 \% \mathrm{w} / \mathrm{w}$. Ethyl acetate was used as a solvent since it showed the highest flavonoid content among all other solvents of extraction of $C$. pepo leaves in a previous study. ${ }^{21}$ Preliminary screening of phytochemicals of CPLE was conducted and proved the presence of phenols, proteins, flavonoids, alkaloids, saponins, glycosides, gum, carbohydrates, and starch using standard biochemical testing methods ${ }^{13}$. These results are similar to a previously conducted study on phytochemical constituents of $C$. pepo leaves extract using ethyl acetate solvent conducted in India. Phenol and flavonoid both are important phytochemical constituents that have been found in many plants, including vegetables and fruits. The polyphenol content correlates to the antioxidant effect of the plant. ${ }^{22}$ Polyphenols are used as antioxidants in food industrials and pharmaceutical manufacturers because of their beneficial health effects. Phenol and flavonoid as polyphenols had anti-diabetic, anti-hypertensive, anti-inflammatory, cardiac, and cerebrovascular protection effects along with its antioxidant effect ${ }^{23,24}$ For the present study, the FolinCiocalteu procedure was processed to estimate the TPC, and Gallic acid (reference standard) was used. The calibration curve was presented in a range of $10-1000 \mu \mathrm{g} / \mathrm{mL}$ (Fig.-1a). The regression value was quantified as $\mathrm{R}^{2}=0.9786$ and the TPC were estimated as $32.6 \pm 0.17 \mathrm{mg}$ GAE/g. The Rutin reagent was used as a standard in the TFC estimation. Subsequently, the calibration curve of TFC was set in a range of 10-1000 $\mu \mathrm{g} / \mathrm{mL}$ (Fig.-1b). The regression value estimated was quantified as $\mathrm{R}^{2}=0.9822$. The TFC in CPLE was estimated as $80.5 \pm 0.02 \mathrm{mg} \mathrm{RUE} / \mathrm{g}$.

1a

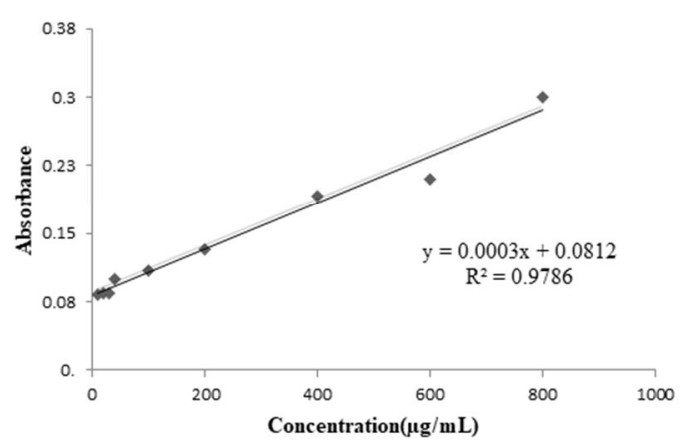

$1 \mathrm{~b}$

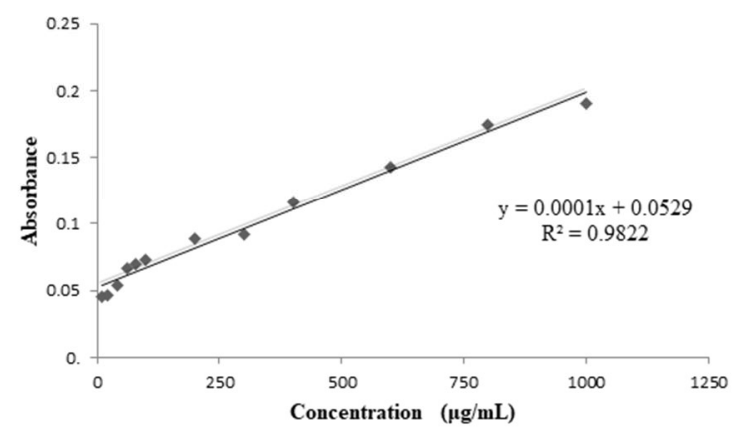

Fig.-1: Standard Calibration Curve (n=3) (a) Gallic Acid for TPC (b) Rutin for TFC

An antioxidant assay using DPPH and ABTS analyses was chosen as sensitive, convenient, and rapid methods to determine radical scavenging abilities ${ }^{25}$, and the results were presented in Fig.-2a and Fig.-2b. DPPH assay estimated to have a comparably good antioxidant activity with an $\mathrm{IC}_{50}: 49.31 \pm 0.21 \mu \mathrm{g} / \mathrm{mL}$ contrasted to standard ascorbic acid with an $\mathrm{IC}_{50}$ equals $33.66 \pm 0.17 \mu \mathrm{g} / \mathrm{mL}$. As well as ABTS analysis showed an $\mathrm{IC}_{50}: 48.67 \pm 0.27 \mu \mathrm{g} / \mathrm{mL}$ contrasted to the standard, which showed an $\mathrm{IC}_{50}: 33.39 \pm 0.11$ $\mu \mathrm{g} / \mathrm{mL}$. 

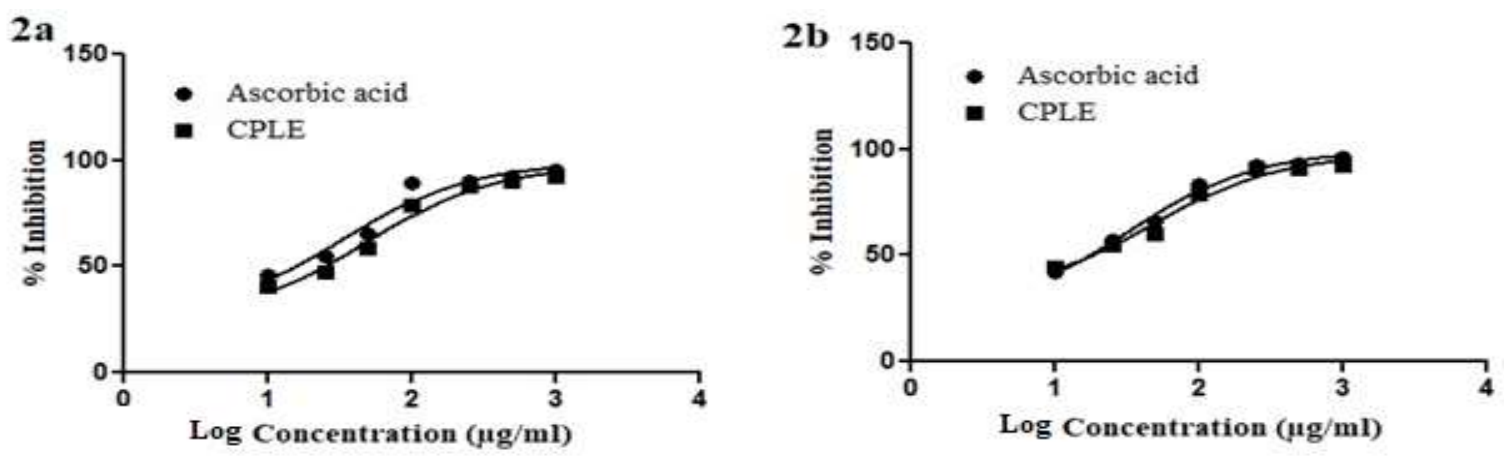

Fig.-2: Radical Scavenging Effect of Ascorbic Acid and CPLE (n=3) (a) DPPH Method (b) ABTS Method

Amylases and glucosidases enzymes act as carbohydrates digestive enzymes that lead to an increase in the digested glucose level in diabetic patients. The inhibition of alpha glucosidase and alpha amylase is especially beneficial in delaying the digestion and absorption of carbohydrates without affecting insulin secretion hence, reducing the risk of development of diabetes mellitus. ${ }^{26}$ In this assay, the enzymatic inhibitory activities were observed using acarbose as a standard drug. The percentage inhibition versus concentration of both CPLE and standard is depicted in Fig.-3a and Fig.-3b. CPLE showed a good alpha amylase inhibitory activity with an $\mathrm{IC}_{50}$ of $24.99 \pm 0.07 \mu \mathrm{g} / \mathrm{mL}$ compared to the standard drug, acarbose which showed an $\mathrm{IC}_{50}: 19.45 \pm 0.19 \mu \mathrm{g} / \mathrm{mL}$. Also, in $\alpha$-glucosidase enzyme inhibitory assay, CPLE showed an $\mathrm{IC}_{50}: 22.29 \pm 0.27 \mu \mathrm{g} / \mathrm{mL}$, whereas acarbose showed an $\mathrm{IC}_{50}$ equal to $16.70 \pm 0.09 \mu \mathrm{g} / \mathrm{mL}$.
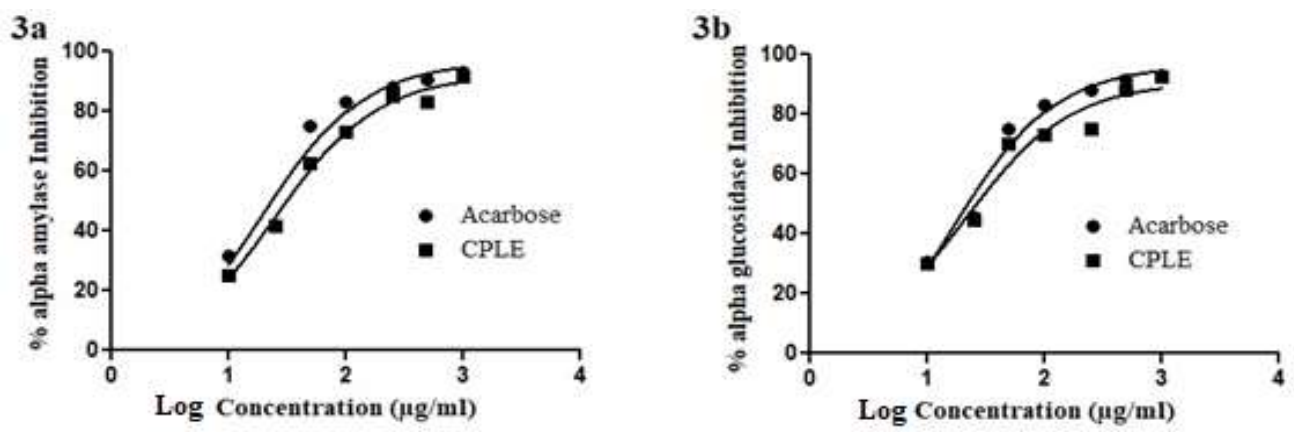

Fig.-3: \% Enzyme Inhibition of CPLE and Acarbose (n=3) (a) $\alpha$-amylase (b) $\alpha$-glucosidase.

\section{CONCLUSION}

The in-vitro studies on ethyl acetate extract of Cucurbita pepo leaves in the present research had concluded the extract potentiality of both antioxidant and anti-diabetic properties. The extract resulted in a high polyphenols content of both the flavonoids and phenols that correlate to the reduction of free radicals or antioxidant activities. Moreover, the extract had shown a significantly high inhibition of alpha glucosidase and alpha amylase enzymes that are beneficial in dietary carbohydrates-induced hyperglycemia. Antioxidant and antidiabetic activities exhibited by natural plants may have the capability to produce the same effect and even better efficacy that could be safer than synthetic agents hence, further investigations on clinical studies on CPLE must be conducted in future studies.

\section{ACKNOWLEDGEMENT}

The authors are thankful to the Deanship of Scientific Research, Qassim University, to fund this project's publication.

\section{REFERENCES}

1. S. Badal and R. Delgoda, Pharmacognosy: Fundamentals, Applications, and Strategies, Academic Press, p.3,13 (2017). 
RASĀYAN J. Chem.

Vol. 14 | No. 4 |2357-2362 | October- December | 2021

2. A. Jafarian, B. Zolfaghari and M. Parnianifard, Research in Pharmaceutical Sciences, 7(4), 217 (2012).

3. R. Damiano, T. Cai, P. Fornara, C. Franzese, R. Leonardi and V. Mirone, Archivio Italiano di Urologia e Andrologia, 88 (2), 136(2016)

4. Z. Naeem, International Journal of Health Sciences, 9(3), 5(2015).

5. G. Nguenang, A. Mbaveng, A. Fankam, H. Manekeng, P. Nayim, B. Wamba and V. Kuete, The Scientifc World Journal, 1 (2018), https://doi.org/10.1155/2018/7651482

6. S. Mondal, I. Hossain and M.N Islam, Journal of Pharmacognosy and Phytochemistry, 6(5), 1016 (2017).

7. T. Karpagam, B. Varalakshmi, J.S and S. Gomathi, International Journal of Pharmaceutical Research \& Development, 3(3), 184 (2011).

8. V. Krimer-Malešević, S. Mađarev-Popović, Ž . Vaštag, L. Radulović and D. Peričin, Phenolic acids in pumpkin (Cucurbita pepo L.) seeds, in: V.R. Preedy, R.R. Watson and V. B. Patel (Eds.), Nuts and seeds in health and disease prevention, Academic Press, p. 925-932 (2011).

9. F. Oloyede, G. Agbaje, E. Obuotor and I. Obisesan, Food Chemistry, 135(2), 460 (2012).

10. K. Nyam, M. Lau and C.Tan, Malaysian journal of nutrition, 19(1), 99 (2013).

11. S. Chigurupati, S. Vijayabalan, K.K. Selvarajan, N.E. Hashish, V. Mani, E.S. Ahmed and S. Das, Indian Journal of Traditional Knowledge, 18, 360(2019).

12. S. Chigurupati, H.S Aladhadh, A. Alhowail, K,K Selvarajan and S. Bhatia, Medicinal Plants International Journal of Phytomedicines and Related Industries, 12(1), 71(2020), http://dx.doi.org/10.5958/0975-6892.2020.00010.6

13. S. Chigurupati, M.R Marri, S. Vijayabalan and K.K Selvarajan, International Journal of PharmTech Research, 11(3),198(2018), http://dx.doi.org/10.20902/IJPTR.2018.11301

14. N.K. Murthy, K. Pushpalatha and C.G. Joshi, Journal of Chemical and Pharmaceutical Research, 3(5), 218(2011).

15. P.S. Devi, B. Satyanarayana and M.T. Naidu, Notulae Scientia Biologicae, 6(4), 474 (2014), https://doi.org/10.15835/nsb649403

16. S. Chigurupati, M. Selvaraj, V. Mani, K. Selvarajan, J. Mohammad, B. Kaveti, H. Bera, V. Palanimuthu, L. Teh and M. Salleh, Bioorganic Chemistry, 67, 9(2016), https://doi.org/10.1016/j.bioorg.2016.05.002

17. R. Rafique, K.M. Khan, S. Chigurupati, A. Wadood, A.U. Rehman, U. Salar, V. Venugopal, S. Shamim, M. Taha and S. Perveen, Bioorganic Chemistry, 94, 103410(2020), https://doi.org/10.1016/j.bioorg.2019.103195

18. U. Salar, K. Khan, S. Chigurupati, M. Taha, A. Wadood, S. Vijayabalan, M. Ghufran and S. Perveen, Scientific Reports, 7(1), 1(2017), https://doi.org/10.1038/s41598-017-17261-w

19. X.J. Li, Z.G. Li, X. Wang, J.Y Han, B. Zhang, Y.J Fu and C.J. Zhao, Food Chemistry, 212, 403(2016)

20. N.K.K. Boaduo, D. Katerere, J.N. Eloff and V. Naidoo, Pharmaceutical Biology, 52 (6), 756 (2014), https://doi.org/10.3109/13880209.2013.869828

21. P. Dar, M. Farman, A. Dar, Z. Khan, R. Munir, A. Rasheed and U. Waqas, Journal of Agricultural Science and Food Technology, 3(6), 103 (2017).

22. H.P. Cane, N. Saidi, M. Mustanir, D. Darusman, R.Idroes and M. Musman, Rasayan Journal of Chemistry, 13(4), 2215 (2020), https://doi.org/10.31788/RJC.2020.1345818

23. R. Cahyani, S. Purwaningsih, and A. Fitria, Journal of Coastal Life Medicine, 3(5), 356(2015), https://doi.org/10.12980/JCLM.3.2015JCLM-2015-0011

24. R. Suthakaran, M.B. Raju, S. Kavimani, P. Venkappayya, R. Kumar, Suganthi C. Sridevi, C. Ratnamani and K. Suganthi, Rasayan Journal of Chemistry, 1(1), 39 (2008).

25. K. Ganesan K and B. Xu, Nutrients, 9(5), 455(2017), https://doi.org/10.3390/nu9050455

26. R. Agustini, I.G. Sanjaya, N. Herdyastuti, and A. Sabarudin, Rasayan Journal of Chemistry, 14(3), 1507(2021), http://doi.org/10.31788/RJC.2021.1436173

[RJC-6455/2021] 